\title{
Membangun Jemaat yang Kontekstual menurut Teori Pembangunan Jemaat Jan Hendriks*
}

\section{Building a Contextual Congregation according to Jan Hendriks' Theory of Congregational Development}

Jul Imantris Harefa ${ }^{\circledR}$, Yunelis Ndraha ${ }^{2}$

1Program Studi S1 Teologi STT Banua Niha Keriso Protestan Sundermann Nias 2STT Banua Niha Keriso Protestan Sundermann Nias

\section{ARTICLE INFO}

Submitted: Augustt25, 2021

Review: October 11, 2021

Accepted: October 29, 2021

Published: October 30, 2021

\section{KEYWORDS}

BNKP, congregation building, contextual, five-factor approach

\section{CORRESPONDENCE}

Phone:

E-mail: harefajulimantris@gmail.com

\begin{abstract}
A B S T R A C T
This article discusses building contextual congregations according to the theory of congregation building with a fivefactor approach. This approach can be considered in developing congregations because this concept offers an effort to present contextual congregations from a sociologicalempirical perspective. This research was conducted at the BNKP's Congregation Hilisoromi Resort 6, using qualitative research methods. The participants consisted of servants and citizens of the congregation; It is determined by purposive sampling technique. Data collected through observations, interviews, and questionnaires; Analyzed with thematic analysis. The study's findings show that in almost all aspects: climate, leadership, structure, goals, and duties, as well as the identity of the congregation, are in poor and conducive condition. Building a congregation with a five-factor approach makes it a living and empowered church because it departs from the congregation's concrete problems and has a fairly straightforward goal: to build a contextual congregation with quality service. The existence of quality ministry according to the theory of church development is by (1) a good atmosphere of life between congregations, (2) leadership that serves and excites, (3) a good structure - the whole relationship is arranged in such a way that both formal and informal relations, individuals and groups, (4) clear goals and tasks, and (5) good and unmistakable identity.
\end{abstract}

\begin{abstract}
A B S TRAK
Artikel ini membahas tentang membangun jemaat yang kontekstual menurut teori pembangunan jemaat dengan pendekatan lima faktor. Pendekatan ini dapat dipertimbangkan dalam mengembangkan jemaat, oleh karena konsep ini menawarkan upaya menghadirkan jemaat yang kontekstual dari perspektif sosiologis-empiris. Penelitian ini dilaksanakan di Jemaat BNKP Hilisoromi Resort 6; menggunakan metode penelitian kualitatif. Sumber data (partisipan) penelitian terdiri dari para pelayan dan warga jemaat; ditentukan dengan teknik purposive sampling. Data dikumpulkan melalui observasi, wawancara dan angket; dianalisis dengan thematic analysis. Temuan penelitian menunjukkan bahwa hampir dalam semua aspek: iklim, kepemimpinan, struktur, tujuan dan tugas, serta identitas jemaat berada dalam kondisi yang kurang baik dan kondusif. Membangun jemaat dengan pendekatan lima faktor menjadikan jemaat sebagai gereja yang hidup dan berdaya karena berangkat dari persoalan-persoalan konkret jemaat; serta memiliki sasaran yang cukup jelas, yakni membangun jemaat yang kontekstual dengan pelayanan yang berkualitas.
\end{abstract}


Mewujudnyatakan pelayanan yang berkualitas menurut teori pembangunan jemaat ialah dengan (1) suasana kehidupan yang baik antar jemaat, (2) kepemimpinan yang melayani dan menggairahkan, (3) struktur yang baik - keseluruhan relasi diatur sedemikian rupa baik relasi formal maupun informal, individu maupun kelompok, (4) tujuan dan tugas yang jelas, serta (5) identitas/jati diri yang baik.

Kata kunci: BNKP, kontekstual, pembangunan jemaat, pendekatan lima faktor

\section{PENDAHULUAN}

G riffiths mengatakan bahwa perkumpulan umat harus mengalami suatu perubahan menuju pembangunan jemaat dalam segala aspek kehidupan. ${ }^{1}$ Dalam 1 Kor. 14:26 diungkap bahwa pembangunan adalah tujuan keseluruhan persekutan atau perkumpulan umat. ${ }^{2}$ Namun, kenyataannya masih banyak jemaat belum menunjukkan perkembangan pelayanan, sesuai dengan tugas panggilan gereja. Hal tersebut terlihat dalam kegiatan dan penataan organisasi yang masih belum baik, persiapan dan pelaksanaan ibadah yang tidak berjalan dengan baik (para pelayan tidak benar-benar mempersiapkan diri dalam pelaksanaan ibadah). Serta kepemimpinan yang tidak menggairahkan (kepemimpinan yang tidak melayani, kurang mendengarkan orang lain dalam komunikasi yang terbuka, kurang membangun kerjasama yang baik kepada sesama pelayan dan juga kepada warga jemaat), tujuan dan tugas yang kurang bahkan tidak jelas dalam struktur yang semestinya.

Realitas sebagaimana diuraikan di atas, dalam penelitian awal penulis di Jemaat BNKP Hilisoromi Resort 6; penulis menemukan beberapa hal, di antaranya perumusan dan penetapan visi serta misi pelayanan gereja yang belum ada, tidak ada keteraturan dalam pelaksanaan pelayanan, kurangnya persiapan pelaksanaan peribadahan di dalam gereja. Pelayanan yang terabaikan, pelaksanaan ibadah (liturgi gerejawi) tidak teratur sebagaimana seharusnya (kadang-kala tidak tahu waktu dan pelaksanaan hari-hari besar gerejawi, warga jemaat tidak mendapat pembinaan atau pemberdayaan). Pembangunan fisik juga tidak berjalan dengan baik. Selain itu, jemaat tidak

*Artikel ini merupakan intisari Skripsi Jul Imantris Harefa, "Strategi Membangun Jemaat dalam Rangka Mengoptimalkan Pelayanan di Jemaat BNKP Hilisoromi Resort 6" (STT BNKP Sundermann, 2021).

${ }^{1}$ Michael Griffiths, Gereja dan Panggilannya Dewasa Ini (Jakarta: BPK Gunung Mulia, 1995), 131.

2 Ibid., 126. mampu menunjukkan identitas/jati dirinya sebagai Kristen.

Ada berbagai akibat yang muncul dengan kondisi jemaat yang seperti itu, di antaranya: warga jemaat kurang berpartisipasi dalam kegiatan-kegiatan gerejawi, warga jemaat malas untuk pergi beribadah dan lebih memilih untuk berada di rumah saja atau berkumpul di warung, mabuk-mabukkan, lalu berjudi. Tak jarang persoalan-persoalan tersebut dilakukan oleh orang Kristen. Warga jemaat menutup diri dengan kegiatan-kegiatan kerohanian (bersikap acuh tak acuh terhadap kegiatan kegerejaan). Keadaan tersebut menjadi pergumulan jemaat setempat yang berakibat pada terjadinya kemerosotan iman, jemaat belum memperlihatkan dirinya sebagai jemaat yang bertumbuh, kesadaran akan pentingnya persekutuan untuk membangun spritualitas dan iman rendah. Hal ini terlihat pada minimnya persekutuan jemaat, bahkan tidak dapat dipungkiri warga jemaat dapat memisahkan diri dari jemaatnya ke denomenasi gereja lain karena pelayanan di jemaat sebelumnya tidak berjalan dengan baik.

Charles Swindoll menjelasksan bahwa gereja tidak menyadari bahwa secara perlahanlahan gereja sedang mengalami penurunan kerohanian. ${ }^{3}$ Oleh karena itu gereja memerlukan suatu cara untuk membangun jemaat ke arah yang lebih baik. Dalam buku Perencanaan Strategis Dalam Gereja dan Pelayanan, diungkap bahwa suatu tindakan yang dilakukan oleh suatu organisasi untuk mencapai sasarannya memerlukan strategi. ${ }^{4}$ Strategi berasal dari bahasa Yunani, strategia, yang berarti tata perkantoran, seni kemiliteran, atau lebih luas lagi, kepemimpinan. ${ }^{5}$

3 Charles R. Swidoll, Un Urgent Call For Renewall (Yogyakarta: ANDI, 2013), 240.

4 R. Henry Migliore et al., Perencanaan Strategis Dalam Gereja Dan Pelayanan (Jakarta: BPK Gunung Mulia, 2010), 87.

5 Ibid., 22. 
Dari uraian kondisi jemaat tersebut di atas, penulis melihat bahwa jika persoalan ini tidak ditangani dengan baik dan tepat, maka dampaknya akan sangat buruk bagi jemaat. Jemaat harus menyadari bahwa suasana kehidupan dalam gereja, kepemimpinan, struktur, tugas dan tujuan, serta identitas merupakan sesuatu yang tidak bisa dianggap remeh karena sangat mempengaruhi perkembangan jemaat itu sendiri.

Pembangunan jemaat memiliki arti yang cukup luas. Menurut Van Hooijdonk dalam Inger Gloria Manimoy, secara teologis kata pembangunan mempunyai skala arti yang luas yakni sebagai "intervensi sistematis dan metodis dalam tindak-tanduk jemaat setempat. Baginya pembangunan jemaat menolong jemaat beriman lokal dengan bertanggung jawab penuh berkembang menuju persekutuan (paguyuban) iman, yang mengantarai keadilan dan kasih Allah."6

Beberapa teori atau temuan penelitian sebelumnya mengungkap bahwa membangun jemaat menuju pertumbuhan gereja harus dengan menekankan visi atau tujuan gereja pada pengutusan tenaga-tenaga penginjilan. ${ }^{7}$ Namun, teori ini secara tidak langsung bersifat eksklusif dan masyarakat dijadikan objek kepentingan gereja. Pengutusan gereja tidak hanya terbatas pada penginjilan (memenangkan jiwa-jiwa), tetapi gereja diutus untuk berkarya menyampaikan Injil (kabar baik) dalam karya konkret yang membangun masyarakat. Jadi, pendekatan ini kurang membumi dan menghargai pluralitas agama. Selain itu, ada teori lain yang mengungkap bahwa gereja perlu menyesuaikan diri dengan hari kini di tengah perubahan zaman saat ini agar terjadi yang namanya kontekstualisasi. ${ }^{8}$ Saat ini masyarakat modern berada dalam konteks masyarakat diaspora; namun gereja masih memiliki model sebagai gereja teritorial, akibatnya gereja mengalami kesulitan untuk melayani

6 Inger Gloria Manimoy, “Kajian Pembangunan Jemaat Terhadap Partisipasi Warga GMIT Likwatang Dalam Pelayanan" (Universitas Kristen Satya Wacana Salatiga, 2019), 1-2.

7 Rick Warren, Pertumbuhan Gereja Masa Kini (Malang: Gandum Mas, 2005), 204.

8 Y. B. Mangunwijaya, Gereja Diaspora (Yogyakarta: Kanisius, 2020), 18. masyarakat modern atau pelayanan gereja kurang mampu menjawab konteks masa kini.

Jan Hendriks dalam bukunya berjudul "Jemaat Vital dan Menarik: Membangun Jemaat dengan Menggunakan Lima Faktor" menjelaskan bahwa untuk membangun jemaat dewasa ini maka perlu analisis yang teliti tentang apa yang terjadi dalam situasi jemaat itu sendiri (harus kontekstual). Selanjutnya dijelaskannya bahwa alangkah baiknya jika jemaat menjadi tempat dimana orang dapat saling menolong secara konkret dan kreatif, saling berpartisipasi atau saling berhubungan satu dengan yang lain. Dalam teori Hendriks, membangun jemaat dengan mengembangkan metode vitalisasi jemaat. Yang dimaksud vitalisasi jemaat adalah proses menjadikan jemaat sebagai gereja yang hidup dan berdaya di tengah dunia ini. ${ }^{9}$

Menurutnya, ada lima faktor yang perlu diperhatikan untuk membangun jemaat berdasarkan metode vitalisasi jemaat. Pertama, iklim - istilah iklim dalam gereja ialah sebagai kombinasi faktor-faktor yang menentukan bagaimana merasakannya sebagai bagian gereja. ${ }^{10}$ Iklim merupakan keseluruhan prosedur dan tata cara pergaulan yang khas bagi organisasi. Yang diharapkan adalah iklim positif, yaitu iklim yang membangkitkan semangat. Ada dua fungsi iklim positif: (1) semakin banyak orang berpartisipasi dengan lebih sering dan senang, hal itu tampak dari absensi yang berkurang; (2) tujuan-tujuan dijangkau dengan lebih sering dan dengan lebih baik. Alasannya adalah dalam organisasi dengan iklim positif, orang berkomunikasi dengan lebih banyak, dengan lebih terbuka, dan dengan lebih jujur; hal tersebut menguntungkan kualitas pelayanan. Yang berlaku untuk organisasi berlaku pula untuk jemaat. Pelaksanaan program-program pelayanan lebih berkualitas apabila iklimnya baik. Dalam iklim seperti ini, anggota jemaat dipandang sebagai subjek yang dihargai dan diperlakukan dengan hormat, terlibat dalam penentuan kebijakan dan perumusan tujuan

9 Jan Hendriks, Jemaat Vital Dan Menarik: Membangun Jemaat Dengan Menggunakan Metode Lima Faktor (Yogyakarta: Kanisius, 2002), 49-65.

10 Ron Jenson and Jim Stevens, Dinamika Pertumbuhan Gereja, 3rd ed. (Malang: Gandum Mas, 2004), 130. 
gereja serta mendapat semua informasi dengan mudah (komunikasi lancar). ${ }^{11}$

Kedua, kepemimpinan - Hendriks mengemukakan tentang kepemimpinan yang membangun semangat (menggairahkan). Kepemimpinan yang dimaksud tampak dalam gaya kepemimpinan yang melayani, pemimpin berbagi kuasa/wewenang dan mau mendelegasikan tugas (kepemimpinan kolektif), mau mendengarkan orang lain dalam komunikasi yang hangat dan terbuka, menghargai kemampuan dan bakat-bakat orang lain, memotivasi orang dengan musyawarah (tidak otoriter) dan melakukan aktivitas yang terkait dengan identitas jemaat. ${ }^{12}$

Ketiga, struktur - struktur menempatkan diri pada posisi yang sentral. Istilah struktur yang dimaksud ialah keseluruhan relasi dan hubungan antara orang yang memegang posisiposisi organisatoris yang formal dan informal, yang institusional dan yang kurang institusional. Struktur merupakan keseluruhan relasi yang diatur sedemikian rupa, baik relasi formal maupun informal, individu maupun kelompok. Hendriks mengemukakan ada tiga struktur yang memuat gabungan tiga bentuk relasi, yaitu gemeinschaft (relasi yang menekankan kebersamaan, keterbukaan, pengorbanan, dan kontak langsung), organization (relasi berdasarkan pada tugas bersama), gesellschaft (relasi yang menghargai kepentingan diri asalkan menurut aturan main yang cocok). Ketiga hal tersebut merupakan satu kesatuan yang tidak boleh dipisahkan. ${ }^{13}$

Keempat, tujuan dan tugas - vitalitas jemaat tidak hanya ditentukan oleh perwujudan iklim, kepemimpinan, dan struktur, melainkan juga ditentukan oleh kualitas tujuan dan tugas. Tujuan ialah sesuatu yang dikejar. Tugas ialah pekerjaan yang disanggupi oleh seseorang atau kelompok. Tujuan dan tugas sangat erat kaitannya. Lewat tugas orang mengejar sesuatu; itulah disebut tujuan. Tujuan mau dilaksanakan dan hal itu membawa ke perumusan 'tugas' melalui 'tujuan'. Yang penting ialah bahwa tujuan itu jelas, konkret, bersama dan

11 Hendriks, Jemaat Vital Dan Menarik: Membangun Jemaat Dengan Menggunakan Metode Lima Faktor, 49-65.

12 Ibid., 66-91.

13 Ibid.

14 Ibid. menggairahkan. Demi pelaksanaan tugas, penting bahwa orang diberi ruang untuk berfungsi sebagai subjek. Tujuan yang dimaksud disini ialah segala sesuatu yang menjadi harapan yang ingin diraih gereja; sedangkan tugas yakni pekerjaan yang disanggupi oleh seseorang atau kelompok. Tujuan dan tugas berhubungan erat. Tujuan dan tugas yang diharapkan adalah tujuan yang menggairahkan (menjadi sumber inspirasi) dan tugas yang menarik. Kelima, identitas identitas akan mengungkapkan dengan baik pandangan tentang realitas jemaat. Dalam faktor ini, jemaat diajak untuk menggumuli jati dirinya. ${ }^{14}$

Pendekatan lima faktor ini membangun gereja dengan tujuan yang jelas, melakukan analisis situasi dan mempertimbangkan konteks masyarakat, membangun komitmen anggota, membangun kemampun anggota dengan pembinaan terstruktur, serta membangun karakter. Pendekatan ini menarik untuk dipertimbangkan dalam penyusunan strategi pembangunan jemaat yang kontekstual. Hal positif yang menarik untuk diperhatikan secara khusus adalah upaya menghadirkan "gereja kontekstual" dengan berangkat dari pengamatan empiris (sosiologis).

Pembangunan jemaat berarti pembangunan umat yang tujuannya supaya program-program yang dibuat diharapkan mampu menjadi berkat untuk seluruh warga gereja serta upaya pemberdayaan jemaat secara teologis-empiris. Penting untuk dipahami bahwa pembangunan jemaat harus menjadikan gereja benar-benar berakar kepada Kristus. ${ }^{15}$ Pembangunan jemaat setidaknya memperhatikan lima aspek penting sebagai pedoman, yakni: bertindak imani dan rasional, bertindak fungsional, terarah pada tujuan dan hasil, bertindak menurut waktu/ berproses, bertindak secara tata ruang/ pengembangan organisasi, dan selalu mengaktifkan atau mengupayakan partisipasi dari seluruh pihak demi pembangunan jemaat. ${ }^{16}$ Pembangunan jemaat berarti pemberdayaan atau pembangunan umat. $^{17}$

15 Harun Hadiwijono, Iman Kristen (Jakarta: BPK Gunung Mulia, 2001), 385.

16 Ibid., 92-108.

17 Timotius K. Susanto, 3 Dimensi Keesaan Dalam Pembangunan Jemaat (Jakarta: BPK Gunung Mulia, 2008), 32. 
Bertolak dari uraian di atas, maka masalah yang hendak diselidiki dalam penelitaan ini adalah bagaimana membangun jemaat yang kontekstual. Berdasarkan rumusan masalah tersebut, tujuan penelitian ini adalah untuk menjelaskan strategi membangun jemaat yang kontekstual menurut teori pembangunan jemaat Jan Hendriks dalam rangka mengoptimalkan pelayanan jemaat.

\section{METODE}

Penelitian ini menggunakan metode penelitian kualitatif, yakni penelitian yang bermaksud untuk memahami fenomena tentang apa yang dialami oleh subjek penelitian. ${ }^{18}$ Penelitian dilaksanakan di Jemaat BNKP Hilisoromi Resort 6. Sumber data dan informan (partisipan) berjumlah 15 keluarga, terdiri dari para pelayan dan warga jemaat yang ditetapkan dengan menggunakan teknik; ditetapkan dengan menggunakan teknik purpose sampling, yakni didasarkan atas kompetensi dan bukan atas dasar keterwakilan. ${ }^{19}$ Data dijaring dengan menggunakan teknik wawancara semi terstruktur, ${ }^{20}$ observasi, ${ }^{21}$ dan angket. Analisis data dilakukan dengan menggunakan thematic analysis, merupakan salah satu cara menganalisa data dengan tujuan untuk mengidentifikasi pola atau untuk menemukan tema melalui data yang telah terkumpul.2223 Dalam hal ini, peneliti menganalisis data-data yang terkumpul berdasarkan wawancara, observasi dan angket; kemudian menyeleksi data-data yang relevan dengan fokus pada tema penelitian. Analisis data tetap dilakukan selamat penelitian berlangsung. ${ }^{24}$

18 Lexy J. Meleong, Metodologi Penelitian Kualitatif (Bandung: Remaja Rosdakarya, 2017).

19 H Russell Bernard and Bernard H. Russell, Research Methods in Anthropology: Qualitative and Quantitative Approaches (Walnut Creek: AltaMira Press, 2006).

${ }^{20}$ Ibid.

21 Brigitte Smit and Anthony J. Onwuegbuzie, "Observations in Qualitative Inquiry: When What You See Is Not What You See," International Journal of Qualitative Methods 17, no. 1 (December 2018): 160940691881676.

\section{TEMUAN PENELITIAN}

Dalam mewujudkan perkembangan pelayanan tentu saja gereja menghadapi banyak kendala dan hambatan, baik dari dalam maupun dari luar gereja itu sendiri. Salah satu jemaat yang menurut penulis belum mengalami perkembangan pelayanan ialah Jemaat BNKP Hilisoromi Resort 6. Jemaat ini merupakan salah satu jemaat dalam wilayah pelayanan Resort 6 BNKP. Jemaat Hilisoromi saat ini sedang diperhadapkan oleh berbagai macam persoalan dan tentunya persoalan-persoalan tersebut megjambat pengembangan pelayanan jemaat.

Pertama, adanya ketidakmampuan gereja (pelayan) untuk menjangkau jemaat (perkunjungan) sehingga mereka lebih terbuka dengan gereja lain dan menerima ajaran gereja lain sebagai standar keselamatan mereka (lih. Hulu, 2021). ${ }^{25}$ Kedua, warga jemaat keliru memahami ajaran dari masing-masing gereja sehingga menjadikan ajaran itu sebagai standar keselamatannya. Ketiga, karena warga jemaat tidak aktif dalam peribadahan dan persekutuan, pemahaman yang dimiliki hanya sebatas apa yang dia pahami bukan dari pengajaran yang tepat.

Berikut ini, penulis menyajikan data hasil observasi, wawancara dan penyebaran angket yang dilakukan selama penelitian berlangsung. Dari data tersebut penulis menyimpulkan bahwa Jemaat BNKP Hilisoromi belum mengalami perkembangan dalam pelayanan.

\section{- Kepemimpinan yang kurang bergairah}

Hasil wawancara dengan responden diperoleh informasi bahwa Jemaat BNKP Hilisoromi belum mengalami perkembangan pelayanan, kemajuan dalam segala bidang pelayanan dalam jemaat hampir tidak terlihat,

22 Heriyanto Heriyanto, "Thematic Analysis Sebagai Metode Menganalisa Data Untuk Penelitian Kualitatif," Anuva 2, no. 3 (November 2018): 317.

${ }^{23}$ Virginia Braun and Victoria Clarke, "Using Thematic Analysis in Psychology," Qualitative Research in Psychology 3, no. 2 (January 2006): 77-101.

24 John W. Creswell, Research Design: Qualitative, Quantitative and Mixed Methods Approaches, 4th ed. (SAGE Publications, Inc, 2014).

25 Yuli Putri Berkati Hulu, “Makna Kristus Sebagai Tujuan Akhir Hukum Taurat Dalam Roma 10:4," HINENI: Jurnal Ilmiah Mahasiswa 1, no. 1 (2021): 1-9, https://hineni.sttsundermann.ac.id/index.php/hjim/ar ticle/view/22. 
selain itu Guru Jemaat sebagai pemimpin jemaat tidak menunjukkan integritas diri sebagai pelayan $\left[R_{1}, 7 / 5\right]$.

\section{- Hubungan yang Kurang Baik antar Warga} Jemaat

Pernyataan yang sama juga disampaikan oleh responden lain, menyatakan bahwa Jemaat BNKP Hilisoromi belum menunjukkan dirinya sebagai gereja yang bertumbuh dan berkembang. Sebagian besar tidak ada gairah pelayan dalam melaksanakan pelayanan dan juga kurang memiliki hubungan yang baik antar sesama $\left[R_{2}, 7 / 5\right]$.

\section{- Struktur, Tugas dan Tujuan yang Belum} Jelas

Warga jemaat yang tidak mau terlibat dalam kegiatan-kegiatan gerejawi karena tugas dan tujuan yang belum jelas. Takutnya, cepat atau lambat Jemaat BNKP Hilisoromi ini dilebur oleh pihak resort $\left[R_{2}, 7 / 5\right]$. Ditambah dengan struktur yang belum jelas, di mana pelayan tidak memiliki kejelasan terhadap posisi dan tugasnya.

\section{- Identitas yang Belum Jelas}

Jemaat Hilisoromi hampir tidak memberikan pengaruh apa-apa terhadap warga jemaatnya, pelayanan yang dilakukan tidak terlihat. Hal ini akhirnya membuat jemaat belum memiliki identitas yang jelas, sehingga mudah untuk menerima ajaran lain dan bergabung dalam organisasi gereja lain yang dianggap lebih berpengaruh dalam pertumbuhan imannya. "Para pelayan belum menjadi pelayan" [ $R_{6}$, 11/5]. Jemaat Hilisoromi sedang berada pada situasi yang sangat memprihatinkan. Segala jenis kegiatan atau pelayanan dalam jemaat tidak berjalan baik $\left[R_{2}, 11 / 5\right]$.

\section{Faktor Internal Gerejawi yang Memengaruhi Optimalisasi Pelayanan}

Pada bagian ini, penulis akan menguraikan faktor-faktor internal gerejawi yang memengaruhi optimalisasi pelayanan berdasarkan pendekatan lima faktor pembangunan jemaat. Diuraikan dalam bentuk variabel-variabel dengan deskripsi kriteria kuat, lemah, stagnan (tidak aktif), serta variable kebutuhan besar jemaat. Data yang penulis peroleh dari hasil wawancara, observasi dan angket dianalis dan disajikan sebagai berikut.
1. Iklim. Kondisi faktual menunjukkan warga jemaat saling mengenal satu sama lain dan saling menyapa. Dari faktor iklim organisasi ditemukan kelemahan di antaranya: kurangnya perhatian anggota jemaat, suasana yang menyenangkan kehidupan bersama dalam gereja masih kurang. Pemerolehan informasi tentang pelayanan gerejawi masih lemah, ibadah yang berhikmat mengalami pasang surut, serta partisipasi anggota jemaat pada kegiatan gerejawi masih minim.

Ada beberapa kondisi yang jarang tampak di dalam jemaat, di antaranya: pemimpin jemaat jarang merespon usul atau pemikiran warga jemaat; peran serta pelayan dalam kehidupan gereja sangat lemah. Dalam kondisi iklim seperti ini, yang menjadi kebutuhan besar adalah terdistribusinya informasi pelayanan gerejawi kepada sesama warga jemaat, memberikan sumbangan pemikiran bagi gereja, merasakan kehadiran Allah dalam ibadah, mendapatkan petunjuk hidup sebagai orang Kristen seusai ibadah, serta pengembangan metode pelayanan yang baik dan menarik.

Dari faktor iklim di atas terlihat bahwa pada umumnya variabel-variabel iklim berada dalam kondisi yang kurang baik, sehingga dapat dikatakan bahwa Jemaat Hilisoromi tidak merasakan kondisi iklim yang positif atau kondusif,

2. Kepemimpinan. Kondisi faktual menunjukkan bahwa para pemimpin jemaat mendorong anggota terlibat dalam kegiatan gerejawi, pimpinan jemaat berbagi tugas dengan orang lain, memberi kesempatan kepada warga jemaat untuk melayani sesuai bakat dan potensi, serta pemimpin jemaat menghargai karya pelayanan orang lain.

Dari faktor kepemimpinan, ditemukan kelemahan di antaranya pimpinan jemaat kurang ramah terhadap warga jemaat, memaksakan kehendak, melaksanakan tugas secara asal (kurang bertanggung jawab). Pemimpin jemaat kurang menghargai pentingnya kerjasama, tidak membimbing warga jemaat yang tidak mampu mengerjakan tugas, serta arah dan tujuan gereja belum jelas. Selain itu, ada beberapa kondisi yang juga jarang terlihat di dalam jemaat, di antaranya tidak jelasnya pelaksanan tugas untuk kebutuhan jemaat, 
keterlibatan langsung dalam kegiatan pelayanan kepada masyarakat masih lemah.

Yang menjadi kebutuhan besar dalam faktor ini, yakni perkunjungan para pelayan, mendengar keluhan dan kritik warga jemaat, membimbing jemaat mengenali bakat dan potensi yang dimiliki, keteladanan pelayan, kemampuan pemimpin jemaat menetukan prioritas program pada kegiatan pelayanan kepada masyarakat, serta pembinaan atau regenerasi.

Dari faktor kepemimpinan di atas dapat dilihat bahwa pada umumnya variabelvariabel kepemimpinan berada dalam kondisi yang kurang baik, sehingga dapat dikatakan bahwa Jemaat Hilisoromi tidak merasakan kepemimpinan yang menggairahkan.

3. Struktur. Kondisi faktual menunjukkan bahwa warga jemaat senang bila dikunjungi oleh sesama warga jemaat, dan membantu memberi jalan keluar atas persoalan hidup yang dialami oleh warga jemaat lainnya. Dari faktor struktur organisasi ditemukan kelemahan di antaranya kurangnya perkunjungan gerejawi, dan lemahnya kepengurusan pelayanan. Selain itu, beberapa kondisi yang memang minim sekali tampak di dalam jemaat, yakni warga tidak saling mengunjungi, komunikasi dan kerjasama antara kelompok pelayanan masih kurang, kelompok pelayanan kurang berfungsi dengan baik.

Beberapa kebutuhan besar dalam faktor ini, yakni komunikasi dan harmonisnya hubungan antar pelayan, pelayan dengan jemaat tanpa disuguhi oleh berbagai bentuk konflik.

Dari faktor struktur di atas terlihat bahwa pada umumnya variabel-variabel struktur berada dalam kondisi yang kurang baik, sehingga dapat dikatakan bahwa keseluruhan relasi dan hubungan antara orang yang memegang posisi-posisi pelayanan; baik relasi formal maupun informal, individu maupun kelompok di Jemaat Hilisoromi tidak berjalan dengan baik.

4. Tujuan dan Tugas. Kondisi faktual dalam faktor tujuan dan tugas belum menunjukkan apa-apa. Kelemahan yang ditemukan di antaranya tujuan gereja lokal masih lemah karena minimnya pemahaman akan tujuan gereja berdasarkan misi Allah, isi tugas yang tidak jelas, ketidaksesuaian antara tugas dan kemampuan pelaksana, kerjasama antar pelayan masih minim, pelaksanaan tugas pelayanan dalam suasana tidak nyaman dan kondusif, serta pengelolaan keuangan gereja yang belum jelas. Beberapa kondisi yang memang jarang terlihat di dalam jemaat, yaitu tujuan gereja tidak tidak dirancang dengan mengikuti perkembangan zaman, tujuan tidak mengikuti persoalan aktual masyarakat. Penjabaran tujuan dalam rencana aksi atau tindakan nyata masih kurang, berbagai kelemahan dalam perencanaan, penetapan tujuan dan pelaksanaan tugas.

Beberapa kebutuhan besar dalam faktor ini, yakni pelayanan diarahkan untuk mencapai tujuan, warga jemaat terlibat dalam perumusan tujuan, kerjasama yang baik dalam melaksanakan pelayanan, serta saling menopang satu dengan yang lain.

Dari faktor tujuan dan tugas di atas terlihat bahwa pada umumnya variabel-variabel tujuan dan tugas berada dalam kondisi yang kurang baik, sehingga dapat dikatakan bahwa harapan yang ingin diraih gereja dan pekerjaan yang seharusnya disanggupi oleh seseorang atau kelompok di Jemaat Hilisoromi tidak berjalan dengan baik.

5. Identitas. Kondisi faktual menunjukkan bahwa ibadah minggu berjalan seperti biasa. Dari faktor tujuan dan tugas ditemukan berbagai kelemahan di dalam semangat hidup sebagai orang Kristen, pembinaan dan pengajaran, pelaksanaaan ibadah. Jumlah warga jemaat yang menurun, sarana dan prasarana terbatas, moralitas yang merosot, keinginan melayani masih minim, tanggung jawab, integritas, kesetiaan, dan ketaatan, serta kurangnya makna akan "imago dei".

Kondisi yang jarang terlihat di dalam jemaat, di antaranya kurangnya pelaksanaan ibadah keluarga dan minat membaca Alkitab.

Dari faktor identitas di atas dapat dilihat bahwa pada umumnya variabel-variabel identitas berada dalam kondisi yang kurang baik, sehingga dapat dikatakan bahwa pandangan tentang realitas (jati diri) jemaat sebagai orang Kristen belum tampak dengan jelas. 


\section{PEMBAHASAN}

Ada beberapa teori atau temuan penelitian sebelumnya yang mengungkap bahwa untuk membangun jemaat, hal yang dilakukan ialah dengan menekankan visi atau tujuan gereja melalui pengutusan tenaga-tenaga penginjilan. Inilah teori yang diungkap oleh Rick Warren dalam bukunya yang berjudul Pertumbuhan Gereja Masa Kini. Warren menawarkan suatu teori pembangunan jemaat dengan cara membawa banyak orang masuk ke dalam gereja. ${ }^{26}$ Untuk mewujudkan hal tersebut, ia menekankan visi atau tujuan gereja pada pengutusan tenaga-tenaga penginjilan. ${ }^{27}$ Dalam pendekatan ini, Warren membangun gereja secara eksklusif dan masyarakat dijadikan objek kepentingan gereja, bahkan Warren memahami pengutusan gereja sebatas penginjilan untuk meraih banyak jiwa baru. Pengutusan gereja tidak terbatas pada penginjilan (memenangkan jiwa-jiwa), tetapi gereja diutus untuk berkarya menyampaikan Injil (kabar baik) dalam karya konkret yang membangun masyarakat.

Sejalan dengan itu, Mangunwijaya mengungkap bahwa untuk membangun jemaat hal yang dilakukan ialah gereja perlu menyesuaikan diri dengan hari kini di tengah perubahan zaman saat ini. ${ }^{28}$ Menurutnya, saat ini masyarakat modern berada dalam konteks masyarakat diaspora; namun gereja masih memiliki model sebagai gereja teritorial, akibatnya gereja mengalami kesulitan untuk melayani masyarakat modern atau pelayanan gereja kurang mampu menjawab konteks masa kini. ${ }^{29}$ Pendekatan teori gereja diaspora ini memang menarik untuk dipertimbangkan dalam membangun jemaat yang kontekstual. Hal positif yang menarik untuk diperhatikan secara khusus adalah upaya menghadirkan "gereja kontekstual" di Indonesia dengan berangkat dari pengamatan empiris (sosiologis). Upaya ini sejalan dengan prinsip teologi praktis, yaitu teori teologis yang berorientasi empiris tentang perantaraan tradisi Kristen dalam praksis masyarakat modern. ${ }^{30}$ Namun perlu analisis lebih lanjut karena teori ini kurang memberi perhatian pada sumber daya tiap-tiap jemaat. Sangatlah perlu juga memperhatikan proses

\footnotetext{
26 Warren, Pertumbuhan Gereja Masa Kini, 112.

27 Ibid., 204.

28 Mangunwijaya, Gereja Diaspora, 18.
}

peralihan jemaat mengikuti perkembangan zaman saat ini yang cukup kompleks.

Membangun jemaat dengan pendekatan lima faktor Jan Hendriks memiliki sasaran yang cukup jelas sebagaimana dijelaskan pada bagian sebelumnya, yakni membangun jemaat yang vital dengan kehidupan jemaat yang melaksanakan pelayanan secara berkualitas, baik dalam persekutuan internal maupun eksternal gerejawi.

\section{KONKLUSI}

Temuan penelitian menujukkan bahwa Jemaat BNKP Hilisoromi Resort 6 benar-benar belum mengalami perkembangan. Pelayanan di jemaat ini masih belum dilaksanakan secara optimal. Hal ini dibuktikan oleh hasil penelitian yang diperhadapkan dengan lima faktor membangun jemaat; hasilnya menunjukkan keadaan yang tidak baik (tidak positif). Hal yang sama juga tak jarang kita temui di gereja-gereja lain.

Jemaat ada karena Allah. Jemaat atau gereja tidak berada karena dirinya sendiri. Itulah sebabnya, pembangunan jemaat harus melihat dirinya dalam desain besar "rencana pembangunan" dari Allah. Dalam desain Allah itu jemaat juga tidak berada untuk dirinya sendiri, melainkan berada untuk melaksanakan rancangan dan misi Allah. Pembangunan jemaat harusnya nyata diberlakukan dan dilaksanakan, dalam dan dari kehidupan semua jemaat Tuhan, tiap hari; bersama dan untuk lingkungan manusia. Tidak memandang jemaat kecil maupun jemaat besar. Pembangunan jemaat baiknya disadari harus menjadi bagian yang tidak boleh hilang dalam jati diri jemaat Tuhan. Dalam KPR 2:17 dinyatakan bahwa jemaat adalah subjek pelaksanaan segala kegiatan di dalam jemaat.

Karena itu, dibutuhkan pembangunan jemaat yang berlaku nyata. Nyata dalam kehidupan jemaat sehari-hari, dalam lingkungan di mana konteks jemaat lokal, serta bagi semua orang. Jemaat harus terlibat dan terus dilibatkan dalam pelaksanaan kegiatan kegerejaan. Hal ini mengingatkan kita pada Firman Tuhan dalam 1

\footnotetext{
29 Ibid., 35.

30 Gerben Heitink and Ferd. Heselaars Hartono, Teologi Praktis: Pastoral Dalam Era Modernitas Postmodernitas (Yogyakarta: Kanisius, 2006), 26.
} 
Petrus 2:9 "kamulah imamat yang rajani". Nats itu memberi pemahaman bahwa seluruh jemaat memiliki peran (sebagai subjek) dalam melaksanakan kegiatan kegerejaan. Semakin jemaat dibangun, maka jemaat harus semakin menunjukkan perkembangan pelayanannya sesuai dengan kondisi dan kebutuhan jemaat bersama lingkungannya.

Perlu disadari bahwa banyak sekali potensi dan kekuatan yang belum disadari dan digunakan. Proses pembangunan jemaat memberi perspektif dan juga harapan. Upaya untuk terus mau menemukan kekuatankekuatan yang sudah disediakan Allah dalam kehidupan berjemaat merupakan langkah yang tepat dari pada hanya diam saja. Jemaat harus dibangun bersama dalam iman, pengharapan dan kasih (1 Korintus 13:13).

Mewujudnyatakan pelayanan yang berkualitas melalui teori pembangunan jemaat ialah dengan (1) suasana kehidupan yang baik antar jemaat, (2) kepemimpinan yang melayani dan menggairahkan, (3) struktur yang baik (keseluruhan relasi yang diatur sedemikian rupa, baik relasi formal maupun informal, individu maupun kelompok), (4) tujuan dan tugas yang jelas, serta (5) identitas/jati diri yang baik.

\section{REFERENSI}

Braun, Virginia, and Victoria Clarke. "Using Thematic Analysis in Psychology." Qualitative Research in Psychology 3, no. 2 (January 2006): 77-101.

Creswell, John W. Research Design: Qualitative, Quantitative and Mixed Methods Approaches. 4th ed. SAGE Publications, Inc, 2014.

Griffiths, Michael. Gereja Dan Panggilannya Dewasa Ini. Jakarta: BPK Gunung Mulia, 1995.

Hadiwijono, Harun. Iman Kristen. Jakarta: BPK Gunung Mulia, 2001.

Heitink, Gerben, and Ferd. Heselaars Hartono. Teologi Praktis: Pastoral Dalam Era Modernitas Postmodernitas. Yogyakarta: Kanisius, 2006.

Hendriks, Jan. Jemaat Vital Dan Menarik: Membangun Jemaat Dengan Menggunakan Metode Lima Faktor. Yogyakarta: Kanisius, 2002.

Heriyanto, Heriyanto. “Thematic Analysis Sebagai Metode Menganalisa Data Untuk Penelitian Kualitatif." Anuva 2, no. 3 (November 2018): 317.

Hulu, Yuli Putri Berkati. "Makna Kristus Sebagai Tujuan Akhir Hukum Taurat Dalam Roma
10:4." HINENI: Jurnal Ilmiah Mahasiswa 1, no. 1 (2021): https://hineni.sttsundermann.ac.id/index.p $\mathrm{hp} / \mathrm{hjim} /$ article/view/22.

Jenson, Ron, and Jim Stevens. Dinamika Pertumbuhan Gereja. 3rd ed. Malang: Gandum Mas, 2004.

Mangunwijaya, Y. B. Gereja Diaspora. Yogyakarta: Kanisius, 2020.

Manimoy, Inger Gloria. "Kajian Pembangunan Jemaat Terhadap Partisipasi Warga GMIT Likwatang Dalam Pelayanan." Universitas Kristen Satya Wacana Salatiga, 2019.

Meleong, Lexy J. Metodologi Penelitian Kualitatif. Bandung: Remaja Rosdakarya, 2017.

Migliore, R. Henry, Robert E. Stevans, David L. Loudon, and B. H. Nababan. Perencanaan Strategis Dalam Gereja Dan Pelayanan. Jakarta: BPK Gunung Mulia, 2010.

Russell, H Russell Bernard and Bernard H. Research Methods in Anthropology: Qualitative and Quantitative Approaches. Walnut Creek: AltaMira Press, 2006.

Smit, Brigitte, and Anthony J. Onwuegbuzie. "Observations in Qualitative Inquiry: When What You See Is Not What You See." International Journal of Qualitative Methods 17, no. 1 (December 2018): 160940691881676.

Susanto, Timotius K. 3 Dimensi Keesaan Dalam Pembangunan Jemaat. Jakarta: BPK Gunung Mulia, 2008.

Swidoll, Charles R. Un Urgent Call For Renewall. Yogyakarta: ANDI, 2013.

Warren, Rick. Pertumbuhan Gereja Masa Kini. Malang: Gandum Mas, 2005. 